\title{
AFIKSASI (PREFIKS DAN SUFIKS) DALAM KOLOM EKONOMI BISNIS DI KORAN JAWA POS EDISI KAMIS 14 NOVEMBER 2019
}

\author{
Miftachul Jannah \\ Program Studi Pendidikan Bahasa dan Sastra Indonesia, \\ Fakultas Ilmu Pendidikan, Universitas Hasyim Asy’ari, jannahmifta656@gmail.com
}

\begin{abstract}
Abstrak
Penulisan penelitian ini bertujuan untuk memaparkan penjelasan Afiksasi yakni prefiks dan sufiks dalam kolom Ekonomi Bisnis di Jawa Pos Edisi Kamis 14 November 2019 sebagai media dalam pelaksanaan jurnal penelitian afiksasi yang meliputi prefiks dan sufiks. Penelitian ini untuk memudahkan cara membedakan afiksasi yakni prefiks dan sufiks dalam Bahasa Indonesia.Di dalam morfologi terdapat proses morfemis salah satunya yakni afiksasi. Afiksasi sendiri ialah suatu proses pembentukan pada kata yang mengalami pengimbuhan atau pembubuhan afiks pada sebuah kata dasar ataupun bentuk dasar. baik itu dari kata dasar tunggal ataupun kompleks. Di dalam proses afiksasi kita akan menemui prefiks, infiks, sufiks, konfiks, dan simulfiks. Dari pembahasan diatas berkenan dengan analisis afiksasi (prefiks dan sufiks) pada kolom ekonomi bisnis di jawa pos edisi 14 november 2019 didapatkan hasil bahwa proses afiksasi khususnya prefiks dan sufiks.Prefiks ialah sebuah afiks yang pengimbuhannya diletakkan pada bagian awal dari sebuah kata dasar atau bentuk dasar. Sedangkan pada proses pengimbuhan itu sendiri biasa kita juga mengenali prefiksasi. Sedangkan sufiks ialah sebuah afiks yang diimbuhkan pada bagian belakang dari kata dasar atau bentuk dasar. Sedangkan pada proses pengimbuhan itu sendiri biasa kita juga mengenali sufiksasi. Apabila kita membahas proses afiksasi, di dalamnya pasti sedikit membahas kata dasar pula dan bentuk dasar. Kata dasar ialah kata yang belum memiliki perubahan, belum mengalami perubahan atau proses morfologis, entah itu semacam proses penambahan imbuhan, proses pengulangan ataupun proses pemajemukan. Bentuk dasar ialah bentuk yang menjadi dasar di dalam proses morfologis, bisa bermacam kata dasar, kata imbuhan, kata ulang, dan dapat pula kata majemuk.
\end{abstract}

Kata kunci : afiksasi, prefiks, dan sufiks.

\begin{abstract}
The purpose of this research is to explain the explanation of Affixation, namely prefixes and suffixes in the Business Economics column in Jawa Pos, Thursday, November 14, 2019 edition as a media in the implementation of affixation research journals, including prefixes and suffixes. This research is to facilitate the way of distinguishing affixation, namely prefixes and suffixes in Indonesian. In morphology there is a morphemic process, one of which is affixation. Affixation itself is a process of forming words that have affixes or affixes to a basic word or basic form. whether it's from a single or complex word. In the process of affixation we will meet prefixes, infixes, suffixes, confixes, and simulfixes. From the discussion above is pleased with the analysis of affixation (prefixes and suffixes) in the column of business economics in the November 14 edition 2019 Java post I found the process of affixation, especially prefixes and suffixes. While in the process of addiction itself we usually recognize prefixation. While suffix is an affix that is added to the back of the basic word or basic form. Whereas in the affixing process itself we usually also recognize suffixation. When we discuss the process of affixation, in it must be discussing a few basic words as well as basic forms. The basic word is a word that has not changed, has not undergone a change or a morphological process, whether it is a kind of adding affixation, repetition or compounding. The basic form is the form that is the basis in the morphological process, can be a variety of basic words, affix words, re-words, and can also compound words.
\end{abstract}

Keywords: affixation, prefix, and suffix. 
DOI:

\section{PENDAHULUAN}

Di era globalisasi sekarang ini banyak orang yang kurang minat membaca madia tulis, salah satunya yakni koran. Seiring perkembangan zaman orang lebih menyukai bersosialisasi bahkan menambah wawasan dengan menggunakan gawai (hand phone), mereka melupakan koran yang bahkan dahulu menjadi alat pokok untuk mendapatkan informasi atau berita. Oleh karena in pada penelitian ini dianalisis betapa pentingnya koran di dalam suatu kelompok masyarakat yang tidak banyak diketahui bahwa dari koran atau surat kabar kita dapat menambah banyak ilmu salah satunya dalam bidang morfologi.

Morfologi adalah suatu kajian dalam ilmu linguistik yang membahas, mengkaji serta menganalisis mengenai bagaimana terbentuknya suatu kata, bagaimana perubahan pada suatu kata, beserta seluk beluknya. Morfologi berasal dari kata morphologie. kata morphologie berasal dari bahasa Yunani morphe yang memiliki arti bentuk serta logos yang memiliki arti ilmu. Di dalam Morfologi sendiri terdapat profes morfemis yang meliputi Afiksasi dan Reduplikasi. Afiksasi sendiri adalah proses pembubuhan pada sebuah kata dasar ataupun bentuk dasar. Dalam proses ini juga melibatkan beberapa unsur yaitu (1) dasar atau bentuk dasar, (2) afiks, dan (3) makna gramatikal yang dihasilkan. Tetapi proses tersebut tidak berlaku untuk semua bahasa. Ada beberapa bahasa yang tidak mengenal proses afiksasi tersebut. Afiksasi dibagi menjadi beberapa bagian yaitu prefiks, infiks, sufiks, konfiks, dan simulfiks. Berdasarkan latar belakang tersebut dapat diketahui apa itu morfologi dan apa saja yang dibahas di dalamnya, sertabagaimana proses morfemis didalam kajian morfologi yang juga meliputi afiksasi. Penelitian ilmiah ini diperuntukan untuk lebih menganalisis proses morfemis yakni afiksasi yang meliputi prefiks dan sufiks pada kolom Ekonomi Bisnis di Jawa Pos Edisi 14 November 2019. Tujuan penulisan penelitian ilmiah ini adalah untuk mengetahui morfologi dalam kajian ilmu linguistik yang didalamnya membahas, menganalisis serta mengkaji perubahan serta terbentuknya suatu kata.

\section{METODE PENELITIAN}

Penelitian ini menggunakan metode kualitatif. Bogdan dan Taylor (Moleong, 2002:3) mendefinisikan pendekatan kualitatif sebagai prosedur penelitian yang menghasilkan data deskriptif berupa kata- kata tertulis atau lisan dari orang-orang dan perilaku yang diamati.

Indikasi dari model penelitian ini yang membedakannya dengan penelitian jenis lainnya, antara lain:

1) adanya latar alamiah;

2) manusia sebagai alat atau instrumen;

3) metode kualitatif;

4) analisis data secara induktif;

5) teori dari dasar (grounded theory);

6) deskriptif;

7) lebih mementingkan proses dari pada hasil;

8) adanya batas yang ditentukan oleh fokus;

9) adanya kriteria khusus untuk keabsahan data;

10) desain yang bersifat sementara.

11)hasil penelitian dirundingkan dan disepakati

bersama. 
DOI:

Teknik pengumpulan data menggunakan teknik baca dan catat. Sedangkan teknik analisis data nalisis data penelitian ini akan dilakukan berdasarkan langkahlangkah berikut:

1. mereduksi data yang terdapat pada Koran Jawa Pos Edisi Kamis 14 November 2019

2. mengenali proses derivasi dan infleksi pada Koran Jawa Pos Edisi Kamis 14 November 2019

3. menganalisis data sesuai dengan teori

4. menyimpulkan hasil analisis proses derivasi dan infleksi Koran Koran Jawa Pos Edisi Kamis 14 November 2019

5.

\section{PEMBAHASAN}

Afiksasi adalah suatu imbuhan yang proses pembentukan kata nya dengan membubuhkan afiks pada sebuah kata dasar atau bentuk dasar, baik itudari kata dasar tunggal ataupun kompleks seperti contoh pada kata pimpin yang mendapatkan imbuhan prefiks meN- pada sebuah kata dasar pimpin dan menjadi memimpin. dan kali ini sya akan membahasa tentang proses afiksasi yakni prefiks dan sufiks.

Prefiks adalah sebuah afiks yang pengimbuhannya diletakkan pada bagian awal dari sebuah kata dasar atau bentuk dasar. Prefiksasi adalah sebuah proses pengimbuhan sebuah bunyi yang ditambahkan pada sebuah kata yang nantinya dapat menghasilkan kata baru yang pada intinya kata tersebut tetap masih berhubungan dengan kata awal ataupun kata dasar. Dan prefiks sendiri adalah imbuhan yang didapatkan dari morfem terikat yang masih digunakan kedalam bentuk kata, tetapi tidak merubah makna pada kata itu sendiri. Dan imbuhan prefiks (kata awalan) ini biasanya disebut juga dengan sebuah kata imbuhan yang ditambahkan pada bagian dari sebuah kata dasar. Pada proses pengimbuhan kata awalan ini dinamakan juga dengan prefiks aksi. Prefiks ini biasanya muncul bersamaan dengan pengimbuhan akhir atau disebut sufiks.

pada $\begin{array}{cc}\text { Prefiksasi me-. } & \text { Morfofonemik } \\ \text { proses } & \text { pengimbuhan }\end{array}$
menggunakan prefiks me- dapat berwujud: a. Pengekalan yang terjadi fonem: b, penambahan fonem: dan $c$ adalah peluluhan fonem.

a. Pengekalan fonem sendiri berarti tidak ada fonem yang berubah, tidak ada yang dilesapkan dan tidak ada yang ditambahkan di dalamnya. Hal tersebut terjadi apabila bentuk dasarnya diawali oleh konsonan r, l, w, y, m, n, ng, dan ny. Contoh:

me + rawat $=$ merawat

me + wasiat $=$ mewasiat

me + yakin $=$ meyakin

me + makan $=$ memakan

me + nanti $=$ menanti

me + nganga $=$ mengaga

me + nyanyi $=$ menyanyi

b. penambahan fonem, yaitu penambahan fonem nasal (bunyi bahasa): $m, n, n g$, dan nge. Penambahan fonem nasal (bunyi bahasa): $m$ biasanya terjadi apabila bentuk dasarnya diawali dengan konsonan b dan f. Contohnya:

me + baca $=$ membaca

me + fokus $=$ memfitnah

penambahan fonem nasal (bunyi bahasa): $n$ biasanya terjadi apabila bentuk dasarnya diawali dengan konsonan: d. Contohnya:

me + duda $=$ menduda 
DOI:

penambahan fonem nasal (bunyi bahasa): ng biasanya terjadi apabila bentuk dasarnya diawali dengan konsonan: g, h, kh, a, l, u, e, dan o . Contohnya:

me + gila $=$ menggila

me + hina $=$ menghina

me + khayal $=$ mengkhayal

me + acak $=$ mengacak

me + iris $=$ mengiris

me + ulas $=$ mengulas

me + elak $=$ mengelak

me + obral $=$ mengobral

penambahan fonem nasal (bunyi bahasa): nge biasanya terjadi apabila buntuk dasarnya hanya terdiri oleh satu kata. Contohnya:

$\mathrm{me}+$ bom $=$ mengebom

c. peluluhan fonem biasanya terjadi bila prefiks me- dibubuhkan kepada bentuk dasar yang diawali dengan konsonan bersuara $s, k, p$, dan t. Contoh:

me + sikat $=$ menyikat

Berikut adalah contoh dari proses afiksasi yakni prefiks:

1. Prefiks (awalan) adalahafiks yang diimbuhkan pada bentuk dasar.

a) prefiks meN- [mengambil], [melatih], [menanam], [membantu], dan [menyadarkan]

b) prefiks peN- [pengikat], [pelatih], [pendatang], [pemukul], [penyayang], dan [pengebom]

c) prefiks ber- [berantai], [bersepeda], dan [belajar]

d) prefiks ter- [terbawa]

e) prefiks di- [ditangkap]

f) prefiks ke- [ketua] dan [kehendak]

g) Prefiks se- [sebuah], [sehari], dan [sekampung]

2. Infiks (sisipan) adalah afiks yang diimbuhkan ditengah bentuk dasar.

a) -el- [telunjuk] dan [gelembung] b) -er- [gerigi] dan [serabut]

c) -em- [gemetar], [gemuruh], [kemilau], dan [temali]

Sufiks adalah sebuah afiks yang diimbuhkan pada bagian belakan dari kata dasar atau bentuk dasar. Sedangkan sufiksasi sendiri adalah proses pengimbuhan kata pada bagian belakang dari sebuah kata dasar atau bentuk dasar tersebut. Pada proses pembentukannya ini makna yang terdapat pada kata berimbuhan ini sendiri dapat berbeda dengan kata awal dari bentuk dasarnya. Dalam kata pertama yang terdapat pada proses sufiksasi sendiri berfungsi sebagai pembentuk kata benda. Seperti halnya sufiks ini bisa muncul bersamaan dengan proses afiksasi lainnya.

3. Sufiks (akhiran) adalah afiks yang diimbihkan diakhir bentuk dasar.

a) -an[pangkalan], [daratan], [timbangan], [hukuman], [larangan], [bulanan], dan [asinan]

b) -i [menaiki] dan [memasuki]

c) -kan[meminjamkan] dan [membesarkan]

d) -man dan -wan [budiman] dan [seniman]

e) -wati [seniwati]

f) -is [egois] dan [novelis]

g) -isasi [sosialisasi] dan [modernisasi]

h) -isme [lapitalisme] dan [liberalisme]

4. Konfiks (awalan dan akhiran) adalah afiks yang berupa morfem terbagi, bagian pertama diawal bentuk dasar, sedangkan bagian yang kedua diakhir bentuk dasar.

a) Per-/-an [pertokoan] dan [pernafasan]

b) peN-/-an [penglihatan] dan [pembukuan]

c) ke-/-an [kebaikan] dan [kekuatan]

5. simulfiks adalah afiks yang dimanifestasikan dengan ciri-ciri 
DOI:

segmental yang dileburkan pada bentuk dasar. Manifestasinya dengan nasalisasi dari fonem yang pertama pada suatu bentuk dasar. Fungsinya membentuk verba atau kata kerja.

a) Kopi $=$ ngopi

b) Soto = nyoto

c) Sate = nyate

d) Kebut = ngebut

Sufiks adalah sebuah afiks yang diimbuhkan pada bagian belakan dari kata dasar atau bentuk dasar. Sedangkan sufiksasi sendiri adalah proses pengimbuhan kata pada bagian belakang dari sebuah kata dasar atau bentuk dasar tersebut. Pada proses pembentukannya ini makna yang terdapat pada kata berimbuhan ini sendiri dapat berbeda dengan kata awal dari bentuk dasarnya. Dalam kata pertama yang terdapat pada proses sufiksasi sendiri berfungsi sebagai pembentuk kata benda. Seperti halnya sufiks ini bisa muncul bersamaan dengan proses afiksasi lainnya.

Berikut adalah contoh proses afiksasi yakni sufiks:

1. -an [pangkalan], [daratan], dan [hukuman]

2. -i [menaiki], [mendalami]

3. -kan [membesarkan], [meminjamkan]

4. -man dan -wan [budiman], [seniman]

5. -wati [pragawati], [seniwati]

6. -is [egois], [novelis]

7. -isasi [sosialisasi], [modernisasi]

8. -isme [liberalisme], [kapitalisme]

Menurut beberapa pendapat dari para ahli tentang prefiksasi:

Menurut Abdul Chaer: prefiks adalah suatu afiks yang pembimbuhannya diletakkan pada bagian awal dari sebuah kata dasar atau bentuk dasarnya.

Menurut Samsuri: prefiks adalah sebuah awalan yang diimbuhkan di depan kata dasar, seperti contoh di awalan di dalam bahasa Indonesia yaitu seperti per-, ter- dan lain sebagainya.

Sedangkan menurut pandangan Ramlan: prefiks adalah suatu afiksasi yang letaknya ditempatkan di paling depan karena imbuhan itu selalu melekat di depan kata dasarnya.

Menurut beberapa pendapat dari ahli mengenai sufiksasi

Menurut pendapat Abdul Chaer: sufiksasi adalah suatu afiks dang pengimbuhannya diletakkan pada bagian belakan dari sebuah kata dasar atau bentuk dasar.

Menurut Samsuri: sufiksasi dijelaskan bahwa imbuhan akhiran yang dibubuhkan pada akhir dari sebuah kata dasar.

Dari sedikit pembahasan dan contoh di atas kita dapat mengetahui apa itu proses afiksasi yakni prefiks dan sufiks, dapat diketauhui pula bagaimana perubahan pada suatu kata apabila kita membubuhkan prefik dan sufiks didalamnya.

Apabila membahas proses afiksasi pasti di dalamnya akan terdapat kata dasar, berikut adalah ulasan mengenai kata dasar. Kata dasar adalah kata yang belum memiliki perubahan, belum mengalami perubahan atau proses morfologis, entah itu semacam proses penambahan imbuhan, proses pengulangan ataupun proses pemajemukan. Bentuk dasar adalah bentuk yang menjadi dasar di dalam proses morfologis, bisa bermacam kata dasar, kata imbuhan, kata ulang, dan dapat pula kata majemuk. 
DOI:

Dari data yang berada di bahasa Indonesia, semua per-/-an dan peN-/-an ialah konfiks yang, sedangkan ke-/-an juga termasuk konfiks, kecuali kata kebagian itu bukan termasuk konfiks disebabkan memiliki arti mendapat bagian. Proses terbentuknya kata kata kebagian ialah awalnya pada kata dasar bagi kemudian diimbuhi oleh sufiks -an jadi bagian setelah itu pada bagian ditambahkan prefiks ke-,sehinggah munculah kata kebagian. Masalah yang mengenai konfiks dalam bahasa indonesia ialah berkaitan dengan bentuk me-/-i dan me-/-kan, kedua bentuk tersebut yang menyatan konfiks, tetapi ada juga yang menyatakan bukan dengan berbagai alasan yang bermacam-macam. Yang menyatakan bukan konfiks memberi beberapa alasan diantaranya bahwa sufiks -i dan sufiks -kan ialah afiks derifativ atau afiks pembentuk kata. Misalnya kata menakuti dan menakutkan memilikim proses pembentukan kata seperti ini, pada awalnya kata takut ditambahkan afiks derifativ -i atau -kan, sehingga terbentuklah kata takuti dan takutkan kemudian jadilah kata menakuti dan menakutkan, jadi prefiks me- pada kata menakuti dan menakutkan ini ialah sebuah afiks inflektif.

Selanjutnya berkaitan dengan prefiks dan sufiks dalam Kolom Ekonomi Bisnis di Jawa Pos Edisi 14 November 2019. Di bawah ini adalah kata-kata yang mengalami proses afiksasi yakni prefiks dan sufiks yang terdapat pada Kolom Ekonomi Bisnis di Jawa Pos Edisi 14 November 201

Penelitian ini menganalisis prefiks serta sufiks dalam Kolom Ekonomi Bisnis di Jawa Pos Edisi 14 November 2019. Dari tabel diatas dapat kita ketahui bagaimana perubahan yang terjadi pada suatu kata dasar. Apabila membahas proses afiksasi diantaranya prefiks dan sufiks, tidaklah lengkap apabila kita tidak mengetahui prefiks dan sufiks sendiri. Prefiks adalah imbuhan yang ditambahkan pada awal dari sebuah kata dasar ataupun bentuk dasar.

Dari Kolom Ekonomi Bisnis di Jawa Pos Edisi14 November 2019 ini mengalami proses pengimbuhan pada bagian awal dari sebuah kata dasar (prefiks) diambil lima contoh dari tabel di atas:

1. Contoh: "merombak" mendapatkan imbuhan "me-" dari sebuah kata dasar "rombak" dan apabila digabung akan menjadi kata "merombak".

2. Contoh: "termasuk" mendapatkan imbuhan "ter-" dari sebuah kata dasar "masuk" dan apabila digabung akan menjadi kata "termasuk".

3. Contoh: "memimpin" mendapatkan imbuhan "meN-" dari sebuah kata dasar "pimpin" dan apabila digabung akan menjadi kata "memimpin".

4. Contoh: "sebagai" mendapatkan imbuhan "se-" dari sebuah kata dasar "bagai" dan apabila digabung akan menjadi kata "sebagai".

5. Contoh: "berkembang" mendapatkan imbuhan "ber-" dari sebuah kata dasar "kembang" dan apabila digabung akan menjadi kata "berkembang".

Berikut ini kutipan dari Kolom Ekonomi Bisnis di Jawa Pos Edisi 14 November 2019 yang mengalami proses pengimbuhan pada bagian belakang kata dasar (sufiks), yaitu:

1. Contoh: "maksimalkan" mendapatkan imbuhan "-kan" dari sebuah kata dasar 
DOI:

"maksimal" dan apabila digabung akan menjadi sebuah kata "maksimalkan".

2. Contoh: "bulanan" mendapatkan imbuhan "-an" dari sebuah kata dasar "bulan" dan apabila digabung akan menjadi sebuah kata "bulanan".

3. Contoh: "ekonominya" mendapatkan imbuhan "-nya" dari sebuah kata dasar "ekonomi" dan apabila digabung akan menjadi sebuah kata "ekonominya".

4. Contoh: "ekonominya" mendapatkan imbuhan "-nya" dari sebuah kata dasar "ekonomi" dan apabila digabung akan menjadi sebuah kata "ekonominya".

Contoh: "landasan" mendapatkan imbuhan "-an" dari sebuah kata dasar "landas" dan apabila digabung akan menjadi sebuah kata "landasan".

5. Contoh: "tingkatkan" mendapatkan imbuhan "-kan" dari sebuah kata dasar "tingkat" dan apabila digabung akan menjadi sebuah kata "tingkatkan".

\section{SIMPULAN}

Dari pembahasan diatas dapat kita simpulkan bawasannya di dalam morfologi terdapat proses morfemis salah satunya yakni afiksasi. Afiksasi sendiri ialah suatu proses pembentukan pada kata yang mengalami pengimbuhan atau pembubuhan afiks pada sebuah kata dasar ataupun bentuk dasar.baik itu dari kata dasar tunggal ataupun kompleks.Di dalam proses afiksasi kita akan menemui prefiks, infiks, sufiks, konfiks, dan simulfiks. Dari pembahasan diatas berkenan dengan analisis afiksasi (prefiks dan sufiks) pada kolom ekonomi bisnis di jawa pos edisi 14 november 2019 didapatkan proses afiksasi khususnya prefiks dan sufiks.
Prefiks ialah sebuah afiks yang pengimbuhannya diletakkan pada bagian awal dari sebuah kata dasar atau bentuk dasar. Sedangkan pada proses pengimbuhan itu sendiri biasa kita juga mengenali prefiksasi.Prefiksasi sendiri ialah sebuah proses pengimbuhan sebuah bunyi yang ditambahkan pada sebuah kata yang nantinya dapat menghasilkan kata baru yang pada intinya kata tersebut tetap masih berhubungan dengan kata awal ataupun kata dasar.

Sedangkan sufiks ialah sebuah afiks yang diimbuhkan pada bagian belakang dari kata dasar atau bentuk dasar. Sedangkan pada proses pengimbuhan itu sendiri biasa kita juga mengenali sufiksasi. Sufiksasi sendiri ialah proses pengimbuhan kata pada bagian belakang dari sebuah kata dasar atau bentuk dasar tersebut. Pada proses pembentukannya ini makna yang terdapat pada kata berimbuhan ini sendiri dapat berbeda dengan kata awal dari bentuk dasarnya. Dalam kata pertama yang terdapat pada proses sufiksasi sendiri berfungsi sebagai pembentuk kata benda.

Apabila kita membahas proses afiksasi, di dalamnya pasti sedikit membahas kata dasar pula dan bentuk dasar. Kata dasar ialah kata yang belum memiliki perubahan, belum mengalami perubahan atau proses morfologis, entah itu semacam proses penambahan imbuhan, proses pengulangan ataupun proses pemajemukan. Bentuk dasar ialah bentuk yang menjadi dasar di dalam proses morfologis, bisa bermacam kata dasar, kata imbuhan, kata ulang, dan dapat pula kata majemuk.

Dari data yang berada di bahasa Indonesia, semua per-/-an dan peN-/-an 
DOI:

ialah konfiks yang, sedangkan ke-/-an juga termasuk konfiks, kecuali kata kebagian itu bukan termasuk konfiks disebabkan memiliki arti mendapat bagian. Proses terbentuknya katakebagian ialah awalnya pada kata dasar bagi kemudian diimbuhi oleh sufiks -an jadi bagian setelah itu pada bagian ditambahkan prefiks ke,sehinggah munculah kata kebagian.

Dari kesimpulan diatas kita dapat mengetahui apa itu proses afiksasi yakni prefiks dan sufiks, dapat diketauhui pula bagaimana perubahan pada suatu kata apabila kita membubuhkan prefiks dan sufiks didalamnya.

\section{DAFTAR PUSTAKA}

Chaer, Abdul. 2014. Linguistik umum edisi revisi. Jakarta: Rineka Cipta.

Chaer, Abdul. 2008. Morfologi Bahasa Indonesia. Jakarta: Rineka Cipta

Jawa Pos. 2019. Pemerintah Rombak Komite Syari'a Surabaya. 14 November.

Lexy J. Moleong. 2002. Metodologi Penelitian Kualitatif. Bandung: PT. Remaja Rosdakarya. 